\title{
HPLC method for analysis of substrate and products in beverage alcohol production'
}

\author{
Eduardo Rosado, ${ }^{2}$ Heriberto Batiz ${ }^{3}$ and Mercedes Vilella
}

\begin{abstract}
A procedure was developed and validated for the determination of sugars by high performance liquid chromatography (HPLC). The system studied consisted of a Sugar-pak column operated continuously and with a methanol flow when not in use, as opposed to manufacturer's instructions, which recommend refrigeration of the column during the weekends when idle. This column is recommended for analysis of sugar products and process streams such as those of beet and sugarcane. Evaluations of this technique included a range of samples and procedure variables necessary to validate the effectiveness of the column. An excellent resolution and reproducibility was obtained among the sucrose, glucose, fructose and ethanal signals. The precision was within the accepted limits of less than $2 \%$ relative standard deviation.
\end{abstract}

\section{RESUMEN}

Cromatografía líquida de alto funcionamiento (HPLC) para analizar el sustrato y los productos en la elaboración de bebidas alcohólicas

Se desarralló y validó un procedimiento para la determinación de azúcares por HPLC. Se logró una buena resolución entre las señales de sacarosa, glucosa, fructosa y etanol con una precisión dentro de los límites aceptados (menos de $2 \%$ en la desviación estándar relativa). La columna usada fue la Sugar-pak de Waters Associates. ${ }^{5}$ Cuando el sistema HPLC no está en uso se deja la columna sin tocar y el sistema con un flujo de metanol. Cuando se vuelve a usar, la regeneración de la columna se logra rápidamente sin perder eficienicia.

\section{INTRODUCTION}

The analysis of sugars in fermented mash, final fermentation products, and their corresponding raw materials is important to the alcoholic fermentation industry. A quantitative analysis of both total and individual sugars in the fermentations is needed for proper assessment of substrate and products. The Lane-Eynon analytical method is currently

'Manuscript submitted to Editorial Board 2 February 1989.

${ }^{2}$ Former Assistant Chemist, Rum Pilot Plant.

${ }^{s}$ Chemist, Consultant, Rum Pilot Plant.

${ }^{4}$ Former Science Research Technician.

${ }^{5}$ Trade names in this publication are used only to provide specific information. Mention of a trade name does not constitute a warranty of equipment or materials by the Agricultural Experiment Station of the University of Puerto Rico, nor is this mention a statement of preference over other equipment or materials. 
the most accurate technique employed by the fermentation industry to determine sugar. However, this method is not specific because with it only total fermentable solids can be analyzed. Alternatively, application of high performance liquid chromatography (HPLC) offering rapid analysis of individual compounds is an ideal solution for analyzing these constituents.

HPLC technology was recently evaluated to identify and quantify individual sugars and other components which ordinarily interfere with the Lane-Eynon-Method. Many variables affect the performance and usage lifetime of HPLC columns. Accordingly, evaluations of this technique included a range of samples, columns, and procedure variables necessary to validate its effectiveness.

\section{MATERIALS AND METHODS}

We used an HPLC system provided with an R-401 refractive index detector, a column temperature control, a heating unit for the mobile phase, and a sugar-pak column. In addition, Sep-pak $\mathrm{C}_{18}$ cartridges and a $0.45 \mu \mathrm{m}$ filter were used in sample pretreatment. Water was prepared fresh daily, treated with $0.02 \mathrm{~g} / \mathrm{L}$ calcium acetate and activated carbon, and filtered with $0.45 \mu \mathrm{m}$ cartridges.

A standard solution was prepared which conformed to sugars and alcohol ordinarily found in fermented mashes and wines:

$\begin{array}{ll}\text { Component } & \text { Concentration } \\ \text { Sucrose } & 1.00 \mathrm{~g} / 100 \mathrm{ml} \\ \text { Glucose } & 1.00 \mathrm{~g} / 100 \mathrm{ml} \\ \text { Fructose } & 1.00 \mathrm{~g} / 100 \mathrm{ml} \\ \text { Ethanol } & 4 \%(\mathrm{~V} / \mathrm{V}) \\ \text { Sorbitol } & 0.35 \mathrm{~g} / 100 \mathrm{ml}\end{array}$

The above components were analyzed by two methods for handling the HPLC column:

Method 1: The HPLC column was refrigerated in accordance with the manufacturer's instructions. Before analyses, the mobile phase was freshly prepared and equilibriated to $60^{\circ} \mathrm{C}$. Separation of $5 \mu \mathrm{l}$ sample was accomplished with column temperature set at $90^{\circ} \mathrm{C}$ and a flow rate of $0.5 \mathrm{ml} / \mathrm{min}$. The chromatographic system was maintained overnight with a flow rate of $0.1 \mathrm{ml} / \mathrm{min}$. On weekends the column was removed from the system and refrigerated at $5^{\circ} \mathrm{C}$, while the remaining system was maintained with a continuous flow of 50/50 water/methanol. To resume work, we equilibriated the column to room temperature, reinstalled it, gave it an initial water flow of $0.1 \mathrm{ml} / \mathrm{min}$, and appropriately conditioned it to $90^{\circ} \mathrm{C}$. Finally, the water flow was adjusted from 0.1 to 0.6 $\mathrm{ml} / \mathrm{min}$ in increments of $0.1 \mathrm{ml} / \mathrm{min}$.

Method 2: The column was installed and retained in the system during 
the weekend with $50 \%$ water/methanol. Its operation was similar to that of method 1. However, the weekend column flow utilized water/ methanol, increasing linear gradient from $100 / 0$ to $50 / 50$, at a system constant flow of $0.3 \mathrm{ml} / \mathrm{min}$. The HPLC system was turned off. To resume work, we reheated it and reversed the gradient from $50 \%$ methanol to $100 \%$ water in $1 \mathrm{~h}$ with a flow rate of $0.3 \mathrm{ml} / \mathrm{min}$. It was then adjusted to $0.6 \mathrm{ml} / \mathrm{min}$. When the column lost resolution its flow was reversed.

Two pre-columns (column guards) were evaluated. One contained Bondapack $\mathrm{C}_{18}$ and the other the same packing employed in the Sugarpak column.

Validation of studies of the HPLC system for sugar analyses was performed with the method of Ficarro and Shah. ${ }^{6}$ Replicate assays of samples having known concentrations are evaluated under identical conditions. By this method relative standard deviation among replicates should not exceed $2 \%$.

A linear study of sucrose concentrations varying from $7.5 \%$ to $60 \%$ was performed by the HPLC method and compared under similar conditions with the Lane-Eynon procedure. The retention times of $15 \mathrm{com}-$ pounds separated from fermented mash and wines were determined by HPLC with Method 2.

\section{RESULTS AND DISCUSSION}

Resolutions were obtained with sample sizes of $5 \mu \mathrm{l}$ or less. The reproducibility was maintained with samples up to $5 \mu \mathrm{l}$. The system's injection loop was reduced to $10 \mu l$ to minimize dead volume, thereby facilitating injection of the most effective sample sizes.

Column guard employing the same material as the Sugar-pak column produced no adverse effects on sample resolution.

Pretreatment of the samples by filtering through $0.45 \mu \mathrm{l}$ filter and Sep-pack $\mathrm{C}_{18}$ gave excellent results. Filtration was used thereafter for all analyses.

Comparisons of results obtained with the HPLC system and handling of the column by method 1 and 2 revealed that method 2 was the more appropriate. Analyses with method 1, when work was resumed on Mondays, indicated a loss of column efficiency. Much time was lost in regeneration of the column with calcium acetate. The HPLC system for sugar analysis was validated by both methods for handling and storage of the column. The results with both procedures are presented in tables 1 and 2. Quantitative analyses with method 1 exceeded the accepted standard deviation value of two percent. This deviation indicated lack of precision. However, analyses by method 2 were well within the accepted $2 \%$ stan-

${ }^{6}$ Ficarro, S. M. and K. A. Shah, 1984. Validation of High Performance Liquid Chromatography and Gas Chromatography Assays. Farmaceutical Manufacturing. 
TABLE 1.-Validations of HPLC technology for sugar and ethanol analyses employing column-handling method 1 (manufacturer-recommended)

\begin{tabular}{lcccc}
\hline Component & $\begin{array}{c}\text { Analysis } \\
\text { performed }\end{array}$ & $\begin{array}{c}\text { Quantity found } \\
(\mathrm{g} / 199 \mathrm{ml})\end{array}$ & $\begin{array}{c}\text { Standard } \\
\text { deviation }\end{array}$ & $\begin{array}{c}\text { Relative standard } \\
\text { deviation }\end{array}$ \\
\hline Sucrose & 13 & 0.95815 & 0.0656 & 6.9 \\
Glucose & 13 & 0.96344 & 0.0330 & 3.4 \\
Fructose & 13 & 0.99185 & 0.0295 & 2.9 \\
Ethanol & 13 & 4.04038 & 0.0850 & 2.1 \\
\hline
\end{tabular}

dard deviation. A chromatogram obtained by method 2 is reproduced in figure 1.

Following the procedure of method 2, we determined retention times of other components found in fermented mash and wines. Results are presented below and in figure 2 . On the basis of these retention times, it is expected that the tartaric acid signal will interfere with the sucrose signal. Moreover, the glycerol signal should similarly interfere with that of ethanol. When these components are all mixed in a homogeneous solution, the retention times revealed increased resolution, particularly when employing the isocratic elution technique.

Data for the linear HPLC detector response and for sugar concentrations are presented below and plotted in figure 3. It is evident that the detector response is not linear over the total range of sugar concentrations.

Compound

Levan

Dextran

Hydrochloric acid

Nicotinic acid

Sulfuric acid

Potassium dihydrogen phosphate

Acetic acid

Tartaric acid

Sucrose

Glucose

Fructose

Glycerol

Ethanol

Sorbitol

Sucrose concentration

$\% \mathrm{w} / \mathrm{v}$

7.5

15.0

30.0

60.0
Retention time (minutes)

4.33

4.46

4.66

4.93

5.06

5.20

5.20

7.15

7.40

8.70

10.40

12.25

12.35

15.45

Area response

$\times 10^{7}$

6.7

13.0

23.9

42.0 


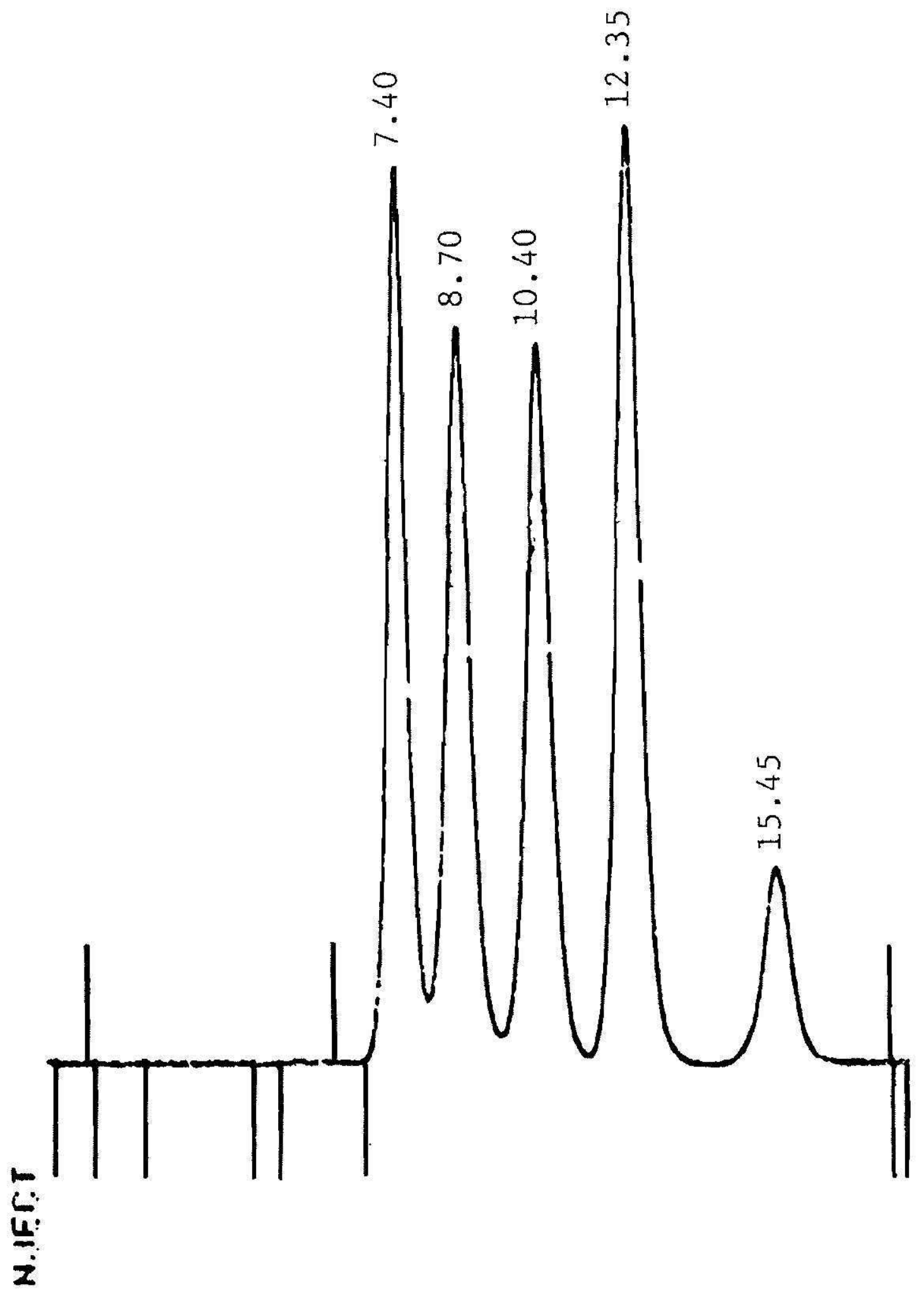

FIG. 1.-Chromatogram of standard solution, Method II. 


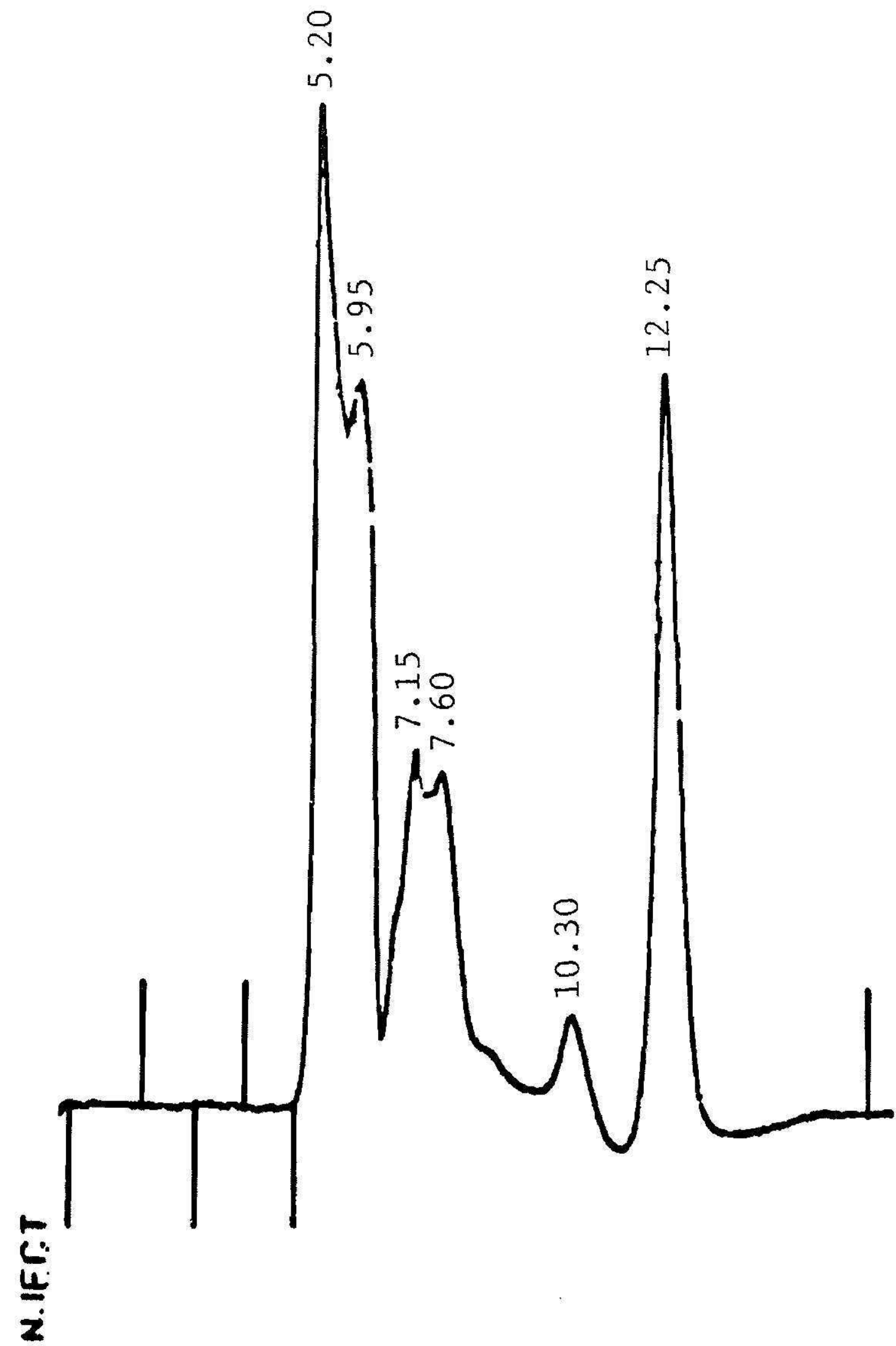

FIG. 2.-Chromatogram of standard solution containing levan, dextran, hydrochloric acid, acetic acid, nicotinic acid, sulfuric acid, potassium dihydrogen phosphate, tartaric acid, and glycerol, Method II. 


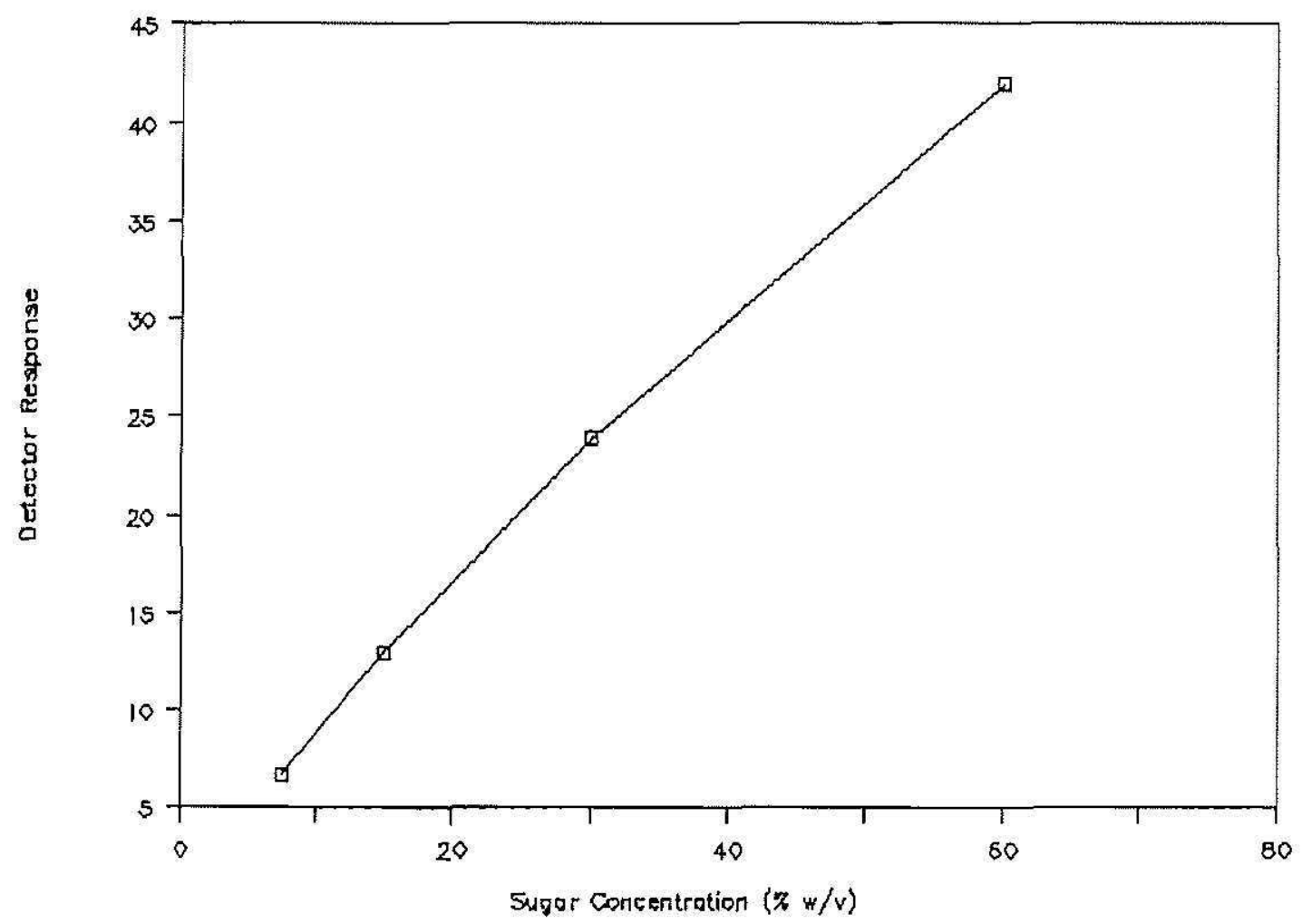

FIG. 3.-Linear response of RI detector.

Sugar-concentration values obtained from standard solutions are presented in table 3. Comparison of the Lane-Eynon and HPLC methods, together with theoretical values, establish the viability of HPLC technology for sugar analyses in beverages.

TABLE 2.-Validations of HPLC technology for sugar and ethanol analyses employing column-handling method 2

\begin{tabular}{lcccc}
\hline Component & $\begin{array}{c}\text { Analysis } \\
\text { performed }\end{array}$ & $\begin{array}{c}\text { Quantity found } \\
(\mathrm{g} / 100 \mathrm{ml})\end{array}$ & $\begin{array}{c}\text { Standard } \\
\text { deviation }\end{array}$ & $\begin{array}{c}\text { Relative standard } \\
\text { deviation }\end{array}$ \\
\hline Sucrose & 10 & 0.9976 & 0.01 & 1.38 \\
Glucose & 10 & 0.9959 & 0.01 & 1.37 \\
Fructose & 10 & 0.9989 & 0.02 & 1.55 \\
Ethanol & 10 & 3.8908 & 0.06 & 1.52 \\
\hline
\end{tabular}

TABLE 3.--Analysis of sucrose by the Lane-Eynon and the HPLC methods, together with theoretical values

\begin{tabular}{cccc}
\hline $\begin{array}{c}\text { Sucrose } \\
\begin{array}{c}\text { concentration } \\
\% \mathrm{w} / \mathrm{v}\end{array}\end{array}$ & $\begin{array}{c}\text { Lane-Eynon } \\
\mathrm{g} / 100 \mathrm{ml}\end{array}$ & $\begin{array}{c}\text { HPLC } \\
\text { Experimental } \\
\mathrm{g} / 100 \mathrm{ml}\end{array}$ & $\begin{array}{c}\text { HPLC } \\
\text { Calculated } \\
\mathrm{g} / 100 \mathrm{ml}\end{array}$ \\
\hline 7.5 & 8.72 & 7.0 & 7.0 \\
15.0 & 17.20 & 14.0 & 14.0 \\
30.0 & 33.70 & 26.2 & 28.0 \\
60.0 & 68.10 & 41.8 & 56.0 \\
\hline
\end{tabular}




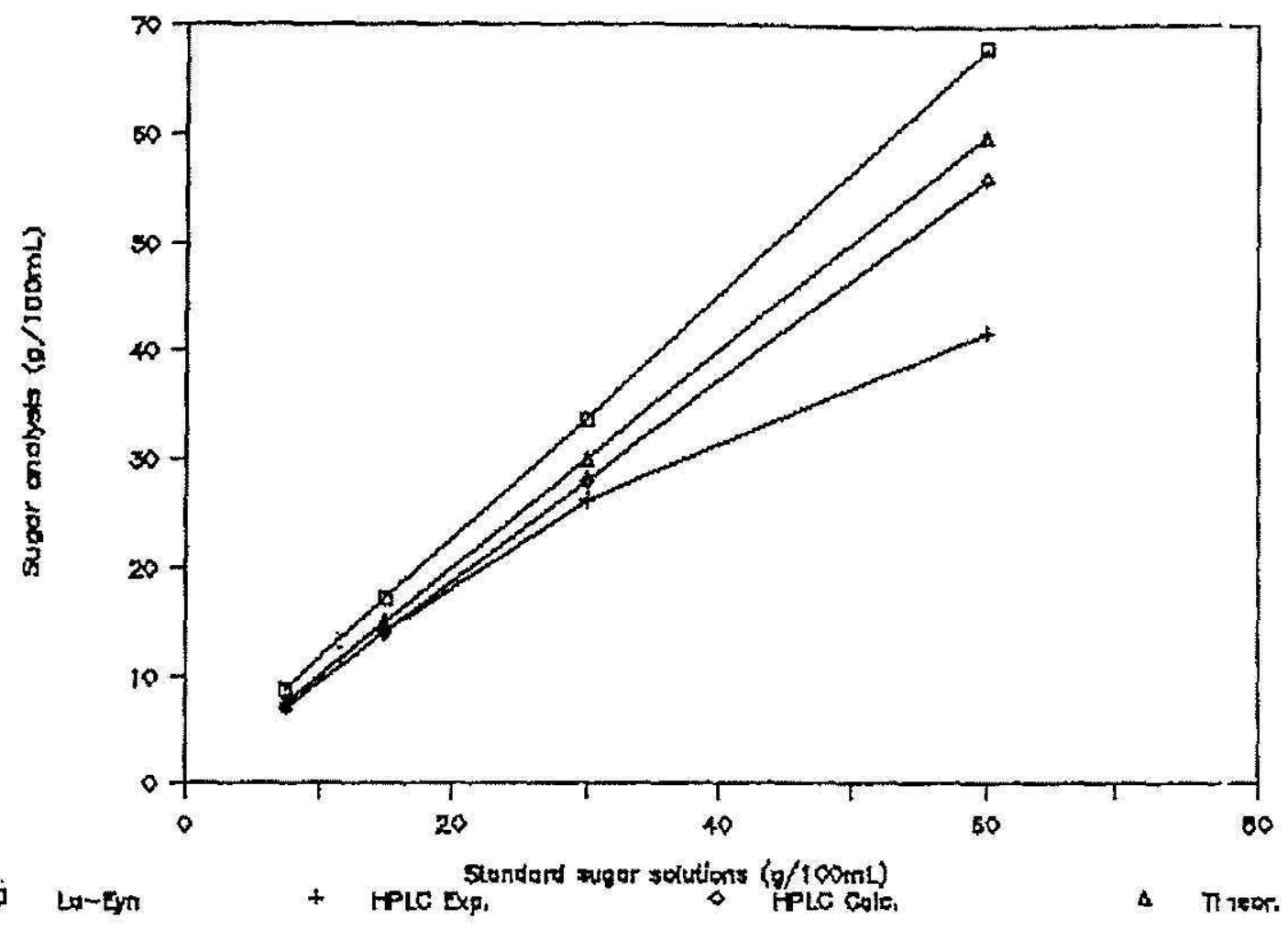

Frg. 4.-Sugar analysis.

Analyses during a fermentation are more rapid by HPLC than by any other method. In about 20 minutes the results are available, a time frame which allows the whole fermentation process to be monitored at once. Another advantage of HPLC technique is that it not only gives quantitative data for all components and total sugars in the medium, but also provides identification of the different sugars present. During a fermentation when using $Z$. mobilis, preference of this microorganism for glucose over other sugars such as sucrose and fructose can be established when all sugars are present. 